\title{
HUBUNGAN TINGKAT PENGETAHUAN TENTANG KEBUTUHAN CAIRAN TUBUH DENGAN POLA KONSUMSI AIR MINUM PADA MAHASISWA TINGKAT I AKPER PANTI KOSALA SURAKARTA
}

\author{
Budi Herminto ${ }^{1}$, Risa Setia Ismandani ${ }^{2}$
}

\begin{abstract}
Water represent compound which is the necessary for all living. Consumption behavior irrigate society not yet altogether goodness, society consume water when feel thirsty and do not so pay attention drinking water and amount matching with requirement. Purpose of the study to determine the relationship between the knowledge level about fluid body requirement with pattern consume drinking water at student in Academy of Nursing Panti Kosala Surakarta.

The subject was used as population in the study was all the first year students. The total population were 139 students, and the sample were 103 students. The sampling technique was simple random sampling.

This research method represent analytic research with design research of corelasional to know relationship between knowledge level about fluid body requirement with pattern consume drinking water of student.

The results was the high level of knowledge about the fluid body requirment were 74 (72\%), moderate level of knowledge about the fluid body requirment were $29(28 \%)$, while the behavior of consuming appropiate water were $69(67 \%)$, and the behavior of consuming inappropiate water were $34(33 \%)$ with a p-value $0.003<0.05$ significant $95 \%$. There was a significant relationship between the knowledge level about fluid body requirement with pattern consume drinking water at student in Academy of Nursing Panti Kosala Surakarta.
\end{abstract}

Keywords: knowlegde level, fluid body requirement, pattern consume drinking water.

\section{PENDAHULUAN}

Air merupakan zat yang penting untuk membuat sel-sel tubuh bekerja, dan bukan merupakan racun. Memasukkan jumlah air yang cukup, membuat tubuh bekerja lebih efisien (Puspitorini, 2009). Menurut Hari (2007), untuk mendapatkan manfaat maksimum, air harus dikonsumsi dengan cara khusus. Air yang diminum bersamaan dengan makanan atau segera setelah makan dapat membahayakan kesehatan, karena air mengencerkan enzim-enzim pencernaan yang menyebabkan pencernaan menjadi sulit. Kebanyakan penyakit berasal dari praktik yang salah ini. Saat pencernaan melambat, racunracun terbentuk dan makanan yang membusuk menyebabkan munculnya gas. Ini juga menghasilkan perasaan yang tidak nyaman di perut. Pada tahap ini, sel-sel menderita dehidrasi dan tidak berada dalam posisi yang siap untuk berperan secara efektif dalam proses pencernaan. Muhammad (2011) menambahkan air memiliki manfaat yang besar bagi tubuh, diantaranya: sebagai pelarut universal, pengatur suhu, pelumas sendi, pengobatan serta mengeluarkan zat-zat sampah dari dalam tubuh. Namun perilaku konsumsi air di kalangan masyarakat belum semuanya baik, misalnya: mayoritas masyarakat mengkonsumsi air minum ketika merasa haus saja, bahkan mereka tidak begitu memperhatikan jumlah 
asupan minum dan jenis minuman yang mereka konsumsi dalam sehari. Kondisi tersebut dapat disebabkan oleh kebiasaan, kebudayaan dan faktor lain misalnya pengetahuan mereka yang kurang tentang manfaat air itu sendiri. Seperti penelitian yang dilakukan oleh Kurnia tahun 2011 mengenai tingkat pengetahuan masyarakat tentang manfaat mengkonsumsi air putih bagi kesehatan tubuh di Dusun VIII Desa Kenangka Kecamatan Cilandak, dimana hasil penelitian tersebut menunjukkan bahwa 26 responden dari 66 responden $(39,4 \%)$ mempunyai pengetahuan kurang dan sebanyak 12 responden $(18,18 \%)$ mempunyai pengetahuan sangat kurang tentang manfaat air.

Demikian halnya dengan mahasiswa Akademi Keperawatan Panti Kosala Surakarta yang mempunyai jadwal perkuliahan cukup padat, rata-rata dimulai pukul 08.00 pagi sampai pukul 16.00 sore. Padatnya jadwal kuliah mahasiswa tersebut tentu saja menuntut stamina tubuh yang baik dan kecukupan cairan tubuh yang optimal. Dari pengamatan yang dilakukan, hanya beberapa mahasiswa yang terlihat membawa bekal air minum pada saat kuliah. Sedangkan yang lain mengatakan tidak menghitung jumlah air yang diminum dalam sehari, beberapa mengatakan minum pada saat haus saja. Padahal menurut Handoyo (2014), tubuh memerlukan asupan air sebanyak 2,5 liter air setiap hari. Berdasarkan uraian tersebut maka peneliti tertarik untuk melakukan penelitian tentang Hubungan Tingkat Pengetahuan tentang Kebutuhan Cairan Tubuh dengan Pola Konsumsi Air Minum pada Mahasiswa Tingkat I di Akademi Keperawatan Panti Kosala Surakarta.

\section{TUJUAN PENELITIAN}

Tujuan umum dari penelitian ini adalah untuk mengetahui hubungan tingkat pengetahuan tentang kebutuhan cairan tubuh dengan pola konsumsi air minum pada mahasiswa tingkat I di Akademi Keperawatan Panti Kosala Surakarta. Adapun tujuan khususnya adalah mengetahui tingkat pengetahuan tentang kebutuhan cairan tubuh pada mahasiswa tingkat I di Akademi Keperawatan Panti Kosala Surakarta dan mengetahui pola konsumsi air minum pada mahasiswa tingkat I di Akademi Keperawatan Panti Kosala Surakarta.

\section{DESAIN PENELITIAN}

Desain penelitian merupakan bentuk rancangan yang digunakan dalam melakukan prosedur penelitian (Hidayat, 2008). Penelitian yang berjudul hubungan antara tingkat pengetahuan tentang kebutuhan cairan tubuh dengan pola konsumsi air minum pada mahasiswa tingkat I Akper Panti Kosala Surakarta ini merupakan penelitian analitik dengan desain korelasional untuk mengetahui hubungan tingkat pengetahuan tentang kebutuhan cairan tubuh sebagai variabel bebas (variabel independen) dengan pola konsumsi air minum sebagai variabel terikat (variabel dependen). Instrumen penelitian ini menggunakan kuesioner yang berisi 20 pertanyaan tingkat pengetahuan dan 1 lembar observasi pola konsumsi air minum. Uji stastitik penelitian ini menggunakan uji ChiSquare program SPSS versi 18.

\section{POPULASI, SAMPEL, DAN TEHNIK SAMPLING}

Populasi pada penelitian ini adalah seluruh mahasiswa Akper Panti Kosala Tingkat I yang berjumlah 139 orang. Pengambilan sampel dalam penelitian ini menggunakan tabel 
Krecjie dengan jumlah 103 responden. Penelitian ini menggunakan teknik simple random sampling, dengan pengambilan sampel yang dilakukan secara acak tanpa memperhatikan strata dalam populasi.

\section{HASIL PENELITIAN}

Pada penelitian ini peneliti akan menguraikan hasil penelitian dengan judul Hubungan antara Tingkat Pengetahuan tentang Kebutuhan Cairan Tubuh dengan Pola Konsumsi Air Minum pada Mahasiswa Tingkat I Akper Panti Kosala Surakarta. Penelitian ini dilakukan pada bulan Maret sampai Juni 2016 dengan jumlah responden sebanyak 103 orang. Penelitian dilakukan dengan menyebarkan kuesioner kepada responden. Di bawah ini akan dipaparkan hasil dari penelitian ini:

1. Tingkat Pengetahuan

Tabel 1.

Distribusi Frekuensi

Tingkat Pengetahuan

Tentang Kebutuhan

CairanTubuh

\begin{tabular}{|c|c|c|}
\hline $\begin{array}{c}\text { Tingkat } \\
\text { Pengetahuan }\end{array}$ & $f$ & $\%$ \\
\hline Tinggi (41-60) & 74 & 72 \\
\hline Sedang (21-40) & 29 & 28 \\
\hline Rendah (0-20) & 0 & 0 \\
\hline Total & 103 & 100 \\
\hline \multicolumn{3}{|c|}{$\begin{array}{l}\text { Dari tabel di atas menunjukkan } \\
\text { persentase tingkat pengetahuan } \\
\text { responden pada kategori tingg } \\
\text { adalah } 72 \% \text { dan kategori sedang } \\
\text { adalah } 28 \% \text {. } \\
\text { 2. Pola Konsumsi Air Minum } \\
\text { Tabel } 2 \text {. } \\
\text { Distribusi Pola Konsumsi Air } \\
\text { Minum }\end{array}$} \\
\hline $\begin{array}{c}\text { Pola kosumsi } \\
\text { Air Minum }\end{array}$ & $f$ & $\%$ \\
\hline Sesuai & 69 & 67 \\
\hline Tidak Sesuai & 34 & 33 \\
\hline Total & 103 & 100 \\
\hline
\end{tabular}

Dari tabel di atas dapat disimpulkan bahwa $67 \%$ responden mempunyai pola konsumsi air minum sesuai kebutuhan sedangkan yang tidak sesuai kebutuhan sebanyak $33 \%$.

3. Hubungan antara Tingkat Pengetahuan tentang Kebutuhan Cairan Tubuh dengan Pola Konsumsi Air Minum Tabel 3.

Tabulasi Silang Hubungan Tingkat Pengetahuan Tentang Kebutuhan Cairan Tubuh dengan Pola Konsumsi Air Minum

Tingkat Pola Konsumsi Jml \begin{tabular}{cccc} 
Pengetahuan & Sesuai & Tidak & \\
\cline { 2 - 4 } Tinggi & 18 & 56 & 74
\end{tabular}

$\begin{array}{llll}\text { Sedang } & 16 & 13 & 29\end{array}$

$\begin{array}{llll}\text { Rendah } & 34 & 69 & 103\end{array}$

Dari tabel di atas responden yang memiliki pengetahuan tinggi dan pola konsumsi air minum sesuai dengan kebutuhan tubuh sebanyak 56 responden. Sedangkan responden yang memiliki pengetahuan sedang dan pola konsumsi tidaksesuai dengan kebutuhan tubuh sebanyak 16 responden. Dari hasil uji Chi-Square program SPSS versi 18.0 dengan $\alpha=5 \%$ $(0,05)$ diperoleh $p$ sebesar 0,003 sehingga nilai $p<0,05$, yang berarti $\mathrm{Ho}$ ditolak dan $\mathrm{H}_{\mathrm{a}}$ diterima sehingga dapat disimpulkan terdapat hubungan antara tingkat pengetahuan tentang kebutuhan cairan tubuh dengan pola konsumsi air minum pada mahasiswa tingkat I Akper Panti Kosala Surakarta.

\section{PEMBAHASAN}

1. Tingkat Pengetahuan

Berdasarkan data karakteristik responden, diperoleh data bahwa sebanyak 60 responden (58\%) berada di usia 19 tahun. Data tersebut menunjukkan bahwa responden sesuai dengan tingkat usianya berada di usia remaja 
lanjut. Menurut Sobur (2010) remaja lanjut merupakan usia yang berada pada rentang usia 17-21 tahun, dimana pada usia tersebut secara kognitif remaja lebih bisa berfikir secara logis dan memiliki wawasan yang lebih luas tentang berbagai aspek kehidupan. Seiring dengan bertambahnya umur seseorang maka pola pikir juga akan berkembang. Usia yang lebih matang akan lebih mudah menerima informasi-informasi baru dalam hal ini terkait cairan tubuh. Dari hasil tabel 1. dapat dicermati bahwa sebagian besar responden yaitu $72 \%$ memiliki pengetahuan yang tinggi tentang kebutuhan cairan tubuh. Menurut Fitriani (2012), pengetahuan merupakan hasil dari tahu dan ini terjadi setelah orang melakukan penginderaan terhadap suatu objek tertentu. Penginderaan terjadi melalui panca indera manusia yakni penglihatan, pendengaran, penciuman, rasa, dan raba. Sebagian besar pengetahuan diperoleh melalui mata dan telinga.

Sesuai dengan pendapat Wawan dan Dewi (2010), pengetahuan dipengaruhi oleh banyak hal dan salah satunya adalah pendidikan. Semakin tinggi tingkat pendidikan semakin tinggi pula pengetahuan tentang suatu hal. Dimana tingkat pendidikan seseorang akan berpengaruh dalam memberi respon terhadap suatu stimulus yang datang dari luar, orang yang berpendidikan tinggi akan memberi respon yang lebih rasional terhadap informasi yang datang.

Responden dalam penelitian ini sedang menjalani pendidikan DIII Keperawatan, sehingga sesuai dengan tingkat pendidikannya responden berada pada strata pendidikan tinggi, dimana hal ini dapat mempengaruhi penerimaan informasi atau pengetahuan seseorang tentang suatu hal. Dalam pendidikan DIII Keperawatan materi-materi terkait dengan cairan tubuh menjadi mata kuliah yang sedang dipelajari, hal ini tentu saja semakin menambah pengetahuan responden tentang cairan tubuh. Pengetahuan bisa juga diperoleh melalui berbagai media informasi. Dalam hal ini responden sebagai mahasiswa keperawatan sering menemukan informasi terkait kebutuhan cairan tubuh melalui buku-buku pelajaran kuliah, internet, poster di rumah sakit, TV, dan media masa lainnya.

Selain dari beberapa faktor tersebut, pengetahuan juga dipengaruhi oleh lingkungan dan kebiasaan. Hal ini sesuai dengan yang disampaikan Wawan dan Dewi (2010), bahwa faktor-faktor yang mempengaruhi tingkat pengetahuan seseorang adalah lingkungan dan sosial budaya. Lingkungan berpengaruh terhadap proses masuknya pengetahuan ke dalam individu karena adanya interaksi timbalbalik yang akan direspon sebagai pengetahuan. Lingkungan memberikan pengaruh pertama bagi seseorang, dimana seseorang dapat mempelajari hal-hal yang baik maupun buruk dalam lingkungan, seseorang akan memperoleh pengalaman yang akan mempengaruhi cara berpikirnya.

Dalam hal ini responden secara langsung dihadapkan pada kondisi yang menuntut untuk meningkatkan derajat kesehatan, misalnya secara fisik responden sebagai mahasiswa keperawatan harus memiliki stamina yang baik, mampu menjaga asupan makanan dan cairan, serta kesehatan agar suatu hari responden bisa memberi contoh 
dan mengajarkan pada orang lain tentang hidup yang sehat, dalam hal ini terkait tentang kebutuhan cairan tubuh. Selain itu, kebiasaan atau tradisi yang dilakukan orang lain baik keluarga, teman, dosen, atau masyarakat yang sering ditemui akan memberikan informasi tentang suatu hal dalam diri individu. Misalnya saja responden sering berinteraksi dengan tenaga kesehatan seperti perawat dan juga dosen Akper yang tentu saja akan memberikan contoh untuk selalu berperilaku mengkonsumsi air dengan tepat dan benar. Sehingga secara perlahan kebiasaan dengan sendirinya akan mempengaruhi pengetahuan individu.

2. Pola Konsumsi Air Minum

Dalam penelitian ini sebagian besar responden mempunyai pola atau perilaku yang baik dalam mengkonsumsi air minum yang ditunjukkan dengan nilai mean jumlah konsumsi air sebesar 2209 cc dalam satu hari. Dimana menurut Handoyo (2014), tubuh memerlukan air sebanyak 2,5 liter setiap hari. Menurut Wawan dan Dewi (2010), pola atau perilaku konsumsi air minum responden dipengaruhi oleh usia. Dari data ditunjukkan mayoritas responden berada pada fase usia remaja, usia remaja merupakan usia peralihan dari masa anak-anak menjadi dewasa. Dalam usia tersebut remaja akan mengalami banyak perubahan dalam dirinya baik fisik, biologis, maupun psikologis. Menurut Sobur (2010), usia remaja lanjut (17-21 tahun) memiliki ciri-ciri mempunyai cita-cita tinggi, bersemangat, dan mempunyai energi yang besar.

Apabila dikaitkan dengan penelitian ini maka responden dalam usianya memiliki semangat yang tinggi untuk meraih sesuatu, melakukan aktivitas-aktivitas yang memerlukan banyak energi dan pikiran seperti kuliah, bekerja atau menjalin hubungan dengan masyarakat secara mandiri. Tentu saja aktivitas tersebut membutuhkan kondisi fisik yang prima, dan secara fisiologis tubuh memerlukan lebih banyak asupan cairan supaya dapat melakukan fungsinya dengan baik. Seperti yang dikemukakan oleh Wardani (2014), bahwa apabila tubuh kekurangan air dapat berdampak negatif pada tingkat kinerja, kognitif, dan mood serta dapat mengurangi stamina tubuh, menurunkan kemampuan mental, dan mengakibatkan kelelahan fisik.

3. Hubungan antara Tingkat Pengetahuan tentang Kebutuhan Cairan Tubuh dengan Pola Konsumsi Air Minum

Berdasarkan analisa bivariat dengan uji Chi-Square program SPSS versi 18 dengan $\alpha=5 \%$ $(0,05)$ diperoleh $p$ sebesar 0,003 sehingga nilai $p<0,05$, yang berarti Ho ditolak dan $\mathrm{H}_{\mathrm{a}}$ diterima, sehingga dapat ditarik kesimpulan bahwa ada hubungan antara tingkat pengetahuan tentang kebutuhan cairan tubuh dengan pola konsumsi air minum mahasiswa tingkat I Akper Panti Kosala Surakarta.

Pola atau perilaku merupakan respon atau reaksi seseorang terhadap stimulus atau rangsangan dari luar. Pola atau perilaku seseorang dipengaruhi oleh banyak hal, salah satunya adalah pengetahuan. Pengetahuan merupakan domain kognitif yang membentuk perilaku seseorang. Dari data diketahui 74 responden memiliki pengetahuan yang tinggi tentang kebutuhan cairan tubuh dan 56 responden 
diantaranya memiliki pola konsumsi air minum yang sesuai. Hal ini menunjukkan bahwa pola konsumsi air minum yang baik didasari oleh pengetahuan yang tinggi tentang kebutuhan cairan, manfaat cairan, akibat kekurangan cairan, dan jumlah asupan cairan.

Dengan demikian tingkat pengetahuan tinggi yang dimiliki responden dapat diartikan bahwa responden memahami serta mampu mengaplikasikan tingkat pengetahuan yang diperoleh, hal ini sesuai pendapat Notoatmodjo (2007) pada tingkatan kognitif memahami dan aplikasi, bahwa responden memiliki kemampuan untuk menjelaskan secara benar kepada obyek yang diketahui dan dapat menginterpretasikan materi itu secara benar serta munculnya kemampuan untuk menggunakan materi yang telah dipelajari pada situasi atau kondisi real.

Perilaku di dalam diri seseorang terjadi melalui proses berurutan, yakni seseorang akan menyadari (Awareness) setelah mengetahui stimulus (objek) terlebih dahulu. Kemudian seseorang akan merasa tertarik (Interest) terhadap stimulus atau objek tersebut, di sini sikap subjek mulai timbul. Setelah itu seseorang akan menimbangnimbang (evaluation) terhadap baik dan tidaknya stimulus tersebut bagi dirinya. Apabila stimulus dirasa baik seseorang akan mencoba (trial) melakukan sesuatu sesuai dengan apa yang diketahuinya dan kemudian seseorang akan berperilaku baik (adoption) pola atau perilaku baik tersebut dalam kehidupannya.

Hasil penelitian ini juga dibuktikan oleh Hafiduddin dan Azlam (2013) bahwa ada hubungan antara pengetahuan tentang manfaat cairan dengan perilaku konsumsi air putih di
Simo Boyolali dengan nilai $p=$ $0,000(<0,05)$. Demikian halnya dengan responden pada penelitian ini dengan tingkat pengetahuan tinggi memungkinkan responden berperilaku baik dalam mengkonsumsi air minum. Hal ini sesuai dengan yang diungkapkan oleh Notoatmodjo (2007) bahwa perilaku yang didasari oleh pengetahuan akan lebih langgeng daripada perilaku yang tidak didasari oleh pengetahuan.

\section{KESIMPULAN}

1. Tingkat pengetahuan tentang kebutuhan cairan tubuh pada mahasiswa tingkat I tergolong tinggi dengan persentase sebanyak $72 \%$.

2. Pola konsumsi air minum responden yang sesuai dengan kebutuhan tubuh adalah $67 \%$ dan yang tidak sesuai kebutuhan tubuh sebanyak $33 \%$.

3. Dari hasil penelitian didapatkan hasil $\mathrm{p}=0,003$, sehingga $p<0,05$ yang berarti Ho ditolak dan $\mathrm{H}_{a}$ diterima, sehingga dapat ditarik kesimpulan bahwa ada hubungan antara tingkat pengetahuan tentang kebutuhan cairan tubuh dengan pola konsumsi air minum pada mahasiswa tingkat I Akper Panti Kosala Surakarta.

\section{SARAN}

1. Diharapkan petugas kesehatan lebih sering melakukan penyuluhan tentang manfaat air minum bagi kesehatan.

2. Diharapkan masyarakat untuk menjaga asupan cairan dengan meningkatkan kebiasaan mengkonsumsi air minum yang benar. 


\section{DAFTAR PUSTAKA}

Fitriani, S. 2012. Promosi Kesehatan. Graha IImu, Yogyakarta.

Handoyo, K. 2014. Khasiat Dan Keajaiban Air Putih. Dunia Sehat, Jakarta.

Hari, A. R. 2007. Terapi Air. Nuansa, Bandung.

Muhammad, A. 2011. Kedahsyatan Air Putih untuk Ragam Terapi Kesehatan. Diva Press, Yogyakarta.

Notoatmodjo, S. 2007. Promosi Kesehatan dan IImu Perilaku. Rineka Cipta, Jakarta.

Puspitorini, M. 2009. Sembuh Berkat Air. Salemba Medika, Jogjakarta.

Sobur, A. 2010. Psikologi Umum. Pustaka Setia, Bandung.

Wardani, R. A. 2014. Terapi Kesehatan dan Kecantikan dengan Air Putih. Notebook, Yogyakarta.
Wawan, A. dan Dewi, M. 2010. Teori dan Pengukuran Pengetahuan Sikap dan Perilaku Manusia. Mulia Medika, Yogyakarta.

Kurnia, N. Pengaruh Pola Minum Air Mineral Terhadap Prestasi. http://ejurnal.stikesprimanusan tara.ac.id/index.php/JKSDIII/article/viewFile/26/24. 2010. Diakses 5 Desember 2015.

Hafiduddin dan Azlam, M. 2016. "Hubungan antara Pengetahuan Manfaat Cairan dengan Perilaku Konsumsi Air Putih". Profesi. Volume 2. Surakarta. Diakses pada tanggal 21 Mei 2016.

${ }^{1}$ Dosen Akper Panti Kosala Surakarta.

${ }^{2}$ Laboran Akper Panti Kosala Surakarta. 
••KOsคเn״ JIK. Vol. 4 No. 2 September 2016 